\title{
Land use change characteristics affected by water saving practices in Manas River Basin, China using Landsat satellite images
}

\author{
Yang Guang ${ }^{1,2}$, Chen Dong ${ }^{1,2}$, He Xinlin ${ }^{1,2 *}$, Long Aihua ${ }^{1,3}$, \\ Yang Mingjie ${ }^{1,2}$, Li Xiaolong ${ }^{1,2}$ \\ (1. College of Water Conservancy and Architectural Engineering, Shihezi University, Shihezi 832000, China; \\ 2. Key Laboratory of Modern Water-Saving Irrigation of Xinjiang Production and Construction Corps, Shihezi 832000, China; \\ 3. China Water Resources \& Hydropower Science Research Institute, Beijing 100038, China)
}

\begin{abstract}
The characteristics and influencing factors of land use change under arid conditions were studied in the Manas River Basin in Xinjiang Region, Northwest China. Landsat satellite images acquired in 1976, 1990, 2000, 2010 and 2015 over the study area were used as basic data. Land use change, the rate of change of land use, land use transfer and other aspects revealed the characteristics of land use change and related factors as influenced by water conditions in the basin. The results showed that: (1) Over nearly 50 years, land reclamation in the Manas River Basin resulted in the rapid expansion of an artificial oasis area, and promoted the process of 'oasis urbanization', and accelerated the development of the river basin economy. (2) In 2000, the popularization of drip irrigation under mulch technology led to the rapid growth of cultivated land and development land in the watershed. Meanwhile, the water table declined in the desert area of the lower reaches of the river basin, and the area occupied by sparse shrub forest and grassland decreased. (3) Before popularization of water-saving technology, woodland, grassland and development land transformed to cultivated land in the amounts of $93.46 \mathrm{~km}^{2}$, $2542.93 \mathrm{~km}^{2}$ and $137.53 \mathrm{~km}^{2}$, respectively, and woodland transformed in the amount of $189.64 \mathrm{~km}^{2}$. After water-saving technology was popularized, woodland, grassland and development land were transformed into cultivated land in the amounts of $567.41 \mathrm{~km}^{2}, 1756.2 \mathrm{~km}^{2}$ and $37.36 \mathrm{~km}^{2}$, respectively. (4) The popularization of water-saving technology made the dynamic degree of cultivated land and development land more active, and further increased landscape fragmentation and landscape heterogeneity. The level of urbanization development, the level of economic development and the dry humidity of the basin became the main factors affecting the change of land use in the basin.
\end{abstract}

Keywords: land-use change, spatial characteristics, influencing factor, Manas River Basin, Landsat satellite images DOI: $10.25165 /$ j.ijabe.20171006.3435

Citation: Yang G, Chen D, He X L, Long A H, Yang M J, Li X L. Land use change characteristics affected by water saving practices in Manas River Basin, China using Landsat satellite images. Int J Agric \& Biol Eng, 2017; 10(6): 123-133.

\section{Introduction}

Changes in land use and land cover are important components of global change, and form the basis of

\section{Received date: 2017-07-29 Accepted date: 2017-11-02}

Biographies: Yang Guang, Associate Professor, research interests: hydrology and water resources, Email: mikeyork@163.com; Chen Dong, Master, research interests: hydrology and water resources, Email: 525824987@qq.com; Long Aihua, PhD, Professor, research interests: hydrology and water resources, Email: ahlong@iwhr.com; aihuadragon@163.com; Yang Mingjie, Master, research interests: hydrology and water resources, Email: studies on land use evolution, structure and function ${ }^{[1,2]}$. These changes are the focus of evolving research on the driving forces that affect landscapes, and they are a highly topical issue in the study of global environmental

1540177719@qq.com; Li Xiaolong, Master, Associate Professor, research interests: hydrology and water resources, Email: 13150401816@163.com.

*Corresponding author: He Xinlin, PhD, Professor, research interests: hydrology and water resources. Key Laboratory of Modern Water-Saving Irrigation of Xinjiang Production and Construction Corps, Shihezi University, Shihezi 832003, China. Tel: +86-15309934677, Email: hexinlin2002@163.com. 
change $^{[3-6]}$.

In the 1990s, land-use and land-cover change research promoted by major international organizations entered a stage of unprecedented prosperity and became the focus of global environmental and sustainable development issues ${ }^{[7,8]}$. Verburg et al. ${ }^{[9]}$ used a land use change model and a world economic integration evaluation model to simulate changes in agricultural land use in 25 European countries, analyzing its driving forces, mechanisms and factors. Tong et al. ${ }^{[10]}$ studied the impacts of climate change and land use change on water resources in the small Miami River Basin in the USA using CA-Markov and HSPF models. Tao et al. $^{[11]}$ used SWAT model to assess the impacts of different land use scenarios on hydrological processes in the Fuhe watershed in Poyang Lake Basin (China) and showed that forest land has a higher capacity to conserve the water as compared to pasture land. Rosa et al. ${ }^{[12]}$ used land use change model, analyzing the assessment of indirect land use change effects and showed that causal-descriptive models appear more suitable for long-term assessments in land use change context while the compared economic models are more suitable for short/medium-term assessments of land use change consequences. The study of land use change in China has mainly focused on the spatiotemporal change process, driving mechanisms and environmental effect $^{[13]}$. Tang et al. ${ }^{[14]}$ systematically summarized the new progress in the theory, method and practical application of the land use/cover change model in China and internationally, and identified problems that need to be solved. Liao et al. ${ }^{[15]}$ used a geographic information system and topographic mapping and remote sensing image data to study land use changes in a coastal zone and to explore land-sea interactions. Zhao et al. ${ }^{[16]}$ analyzed the land use/cover change process and the ecological environment effect of these changes in the Tarim River mainstream area of Xinjiang. Zhang and Zhao ${ }^{[17]}$ studied the temporal and spatial characteristics of land use/cover change in the Yellow River Delta, and quantitatively analyzed the driving factors. Liu et al. ${ }^{[18]}$ analyzed the temporal and spatial pattern of land-use transformation in the farming land of the Huang Huai Hai Plain, and applied spatial econometric regression analysis to analyze the dynamic mechanism of land-use type conversion.

The literature showed important achievements in the study of land use in China and internationally, such as the spatial patterns of land use, land use change model and land use ecological effect. These studies have some theoretical and reference significance for land use management and sustainable utilization, environmental pollution and shortage of water resources caused by regional land use change. However, few studies have examined land use in arid and semi-arid areas where water saving irrigation is widely applied. The Manas River Basin is a typical arid and semi-arid area. With the implementation of water-saving measures, rapid economic development and urbanization occurred in recent years, and the land-use pattern changed dramatically. Therefore, the study of land-use change in the Manas River Basin is of great significance to land use and sustainable development in the basin.

\section{Materials and methods}

\subsection{Description of the study area}

The Manas River Basin $\left(43^{\circ} 27^{\prime}-45^{\circ} 21^{\prime} \mathrm{N}\right.$, $85^{\circ} 01^{\prime}-86^{\circ} 32^{\prime} \mathrm{E}$, Figure 1) is an inland river basin $(340$ $550 \mathrm{~km}^{2}$ ) in a typical arid region of Northwest China, located in the hinterland of the Eurasian continent ${ }^{[19]}$. The basin is in the middle part of the northern slope of the Tianshan Mountains in Xinjiang and the southern margin of the Junggar Basin, and includes Shihezi City, Manas County and surrounding areas. The highest elevation of $5242.5 \mathrm{~m}$ occurs, but the elevation of the plain area is in the range $300-500 \mathrm{~m}$. The basin is far from the sea and has a dry, typically continental climate with high evaporation and little precipitation. The Manas River and the Taxi River are located on the eastern side of the basin, whereas on the western side is the Ning River, Gold River and Bayingou River. The five rivers originate from North Tianshan Mountains and discharge into the Junggar Basin. Among them, the Manas River is the largest river which annual average runoff 
$12.93 \times 10^{8} \mathrm{~km}^{3}$, and it is mainly dependent on peak ice, glacial meltwater and precipitation for recharge ${ }^{[20]}$. At present (2017), the development and utilization rate of surface water resources in the basin is as high as $98 \%$, and the diversion capacity of groundwater resources is as high as $58 \%^{[21]}$.
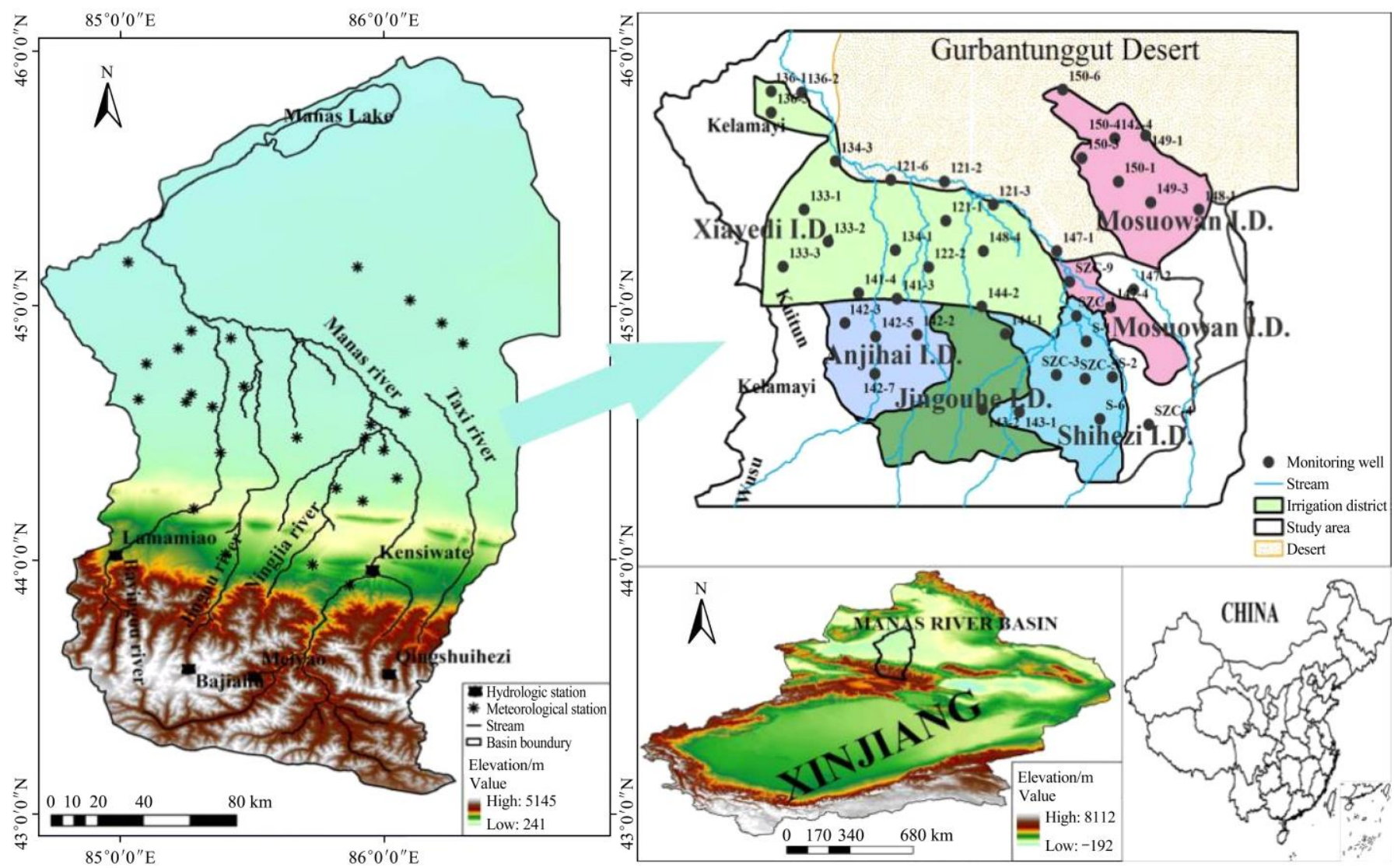

Figure 1 Manas River Basin location

\subsection{Data sources}

Socio-economic data and field research data were used in the study. Among them, the spatial data were mainly remote sensing data derived from Phase 1 Multispectral Scanner System images (1976) and four United States terrestrial satellite Thematic Mapper/ Enhanced Thematic Mapper images (1990, 2000, 2010 and 2015). To meet data quality requirements and to take full account of land-use change characteristics, remote sensing images were selected which were acquired during the highest 8-9 months of vegetation coverage. Social data were obtained mainly from statistical information from the Xinjiang and Shihezi City Bureau of Statistics. Land use data were obtained from the Xinjiang and Shihezi City Land Resources Bureau, and hydrologic data were obtained from the Manas River Basin Management Office. Field research data came mainly from the corresponding years of field inspections.

\subsection{Data processing}

The geometric correction algorithm in the Landsat Ecosystem Disturbance Adaptive Processing System and the orthographic projection algorithm in the Automated Registration and Orthorectification Package software were transplanted and improved to meet the geometric correction and orthographic projection requirements of remote sensing data. According to the characteristics of low cloud pixel temperature and high reflectivity, different thresholds were set, and the two-dimensional space of band temperature and reflectivity was established to distinguish cloud pixels. According to the difference between the surface shadow temperature and the Genting temperature, the height of the cloud was determined. The solar height of the image during image acquisition determines the position of the cloud shadow, from which the pixel of the cloud shadow can be extracted. The remote sensing image was reconstructed using the atmospheric correction module in the ENVI 
software, and the cloud (shadow) pixels were removed ${ }^{[22]}$.

The remote sensing image covering the Manas River Basin was processed and the image was sized according to the vector boundary of the study area. Generated remote sensing image standardized data were used to complete the quality inspection and determine if the interpretation of the remote sensing image required radiation calibration, geometric correction or other aspects of error correction. The remote sensing images were visually interpreted and digitized using ENVI 4.8, ArcGIS 10.1 (ESRI, Redlands, CA, USA) and eCognition 8.6 (Trimble, Inc., Westminster, CO, USA) software ${ }^{[23]}$. The topological relationships were established and the interpretation results were corrected using field study data to obtain land use/land cover data and attribute data.

\subsection{Research methods}

\subsubsection{Single land use dynamic model}

The single land use dynamic degree $\left(R_{1}\right)$ refers to the change of the land-use type in the study area during a certain period of time. This index was used to indicate the change rate and the change range of the land use type in a certain period. A positive $R_{1}$ value indicates an increase in the number of land types with time, whereas $R_{1}$ is reduced when the number of land use types decreases. The mathematical model is as expressed as Equation (1):

$$
R_{1}=\left(U_{b}-U_{a}\right) / U_{a} \times \frac{1}{T} \times 100 \%
$$

where, $R_{1}$ is the degree of land use in a study period; $U_{a}$ and $U_{b}$ are the number of land use types at the beginning of the study period and at the end of the study period, respectively; and $T$ is the length of the study period, when $T$ is a year.

\subsubsection{Comprehensive land use dynamic model}

The comprehensive land use dynamic degree $\left(R_{2}\right)$ indicates changes in the amount of comprehensive land-use types in a certain period of time, and can be used to describe regional differences in the rates of land use type changes. The mathematical model for $R_{2}$ is described by Equation (2):

$$
R_{2}=\sum_{i=1}^{n}\left\{L A_{\left(i, t_{1}\right)}-U L A_{i}\right\} / \sum_{i=1}^{n} L A_{\left(i, t_{1}\right)} /\left(t_{2}-t_{1}\right) \times 100 \%
$$

where, $R_{2}$ is the dynamic degree of comprehensive land-use types during the study period; $i$ is land-use type, $L A_{\left(i, t_{1}\right)}$ represents the area of land change in the $i^{\text {th }}$ class at the beginning of time period; $L A_{\left(i, t_{2}\right)}$ represents the area of land change in the $i^{\text {th }}$ class at the end of the time period, $n$ is the total number of land classes; $U L A_{i}$ stands for area of land type I land conversion into non-I types of land use types, and $t_{1}$ and $t_{2}$ represent the beginning and ending times, respectively.

\subsubsection{Comprehensive index model of land use degree}

The comprehensive index of land use degree is defined by a variety of changes in the structural quality of general land use and reveals the regional land use degree of depth and breadth. As such, this index reflects the comprehensive effect of nature and human activities affecting land use, landscape factors and natural environment factors. The mathematical model for the comprehensive index of land use degree is expressed by Equation (3):

$$
L=100 \times \sum_{i=1}^{n} A_{i} \times C_{i}, L \in[100,400]
$$

$\mathrm{A}_{\text {Unused land }}=1, \mathrm{~A}_{\text {Woodland, grassland, water area }}=2, \mathrm{~A}_{\text {Cultivated land }}=3$, $\mathrm{A}_{\text {Development land }}=4$

where, $L$ is the comprehensive index of regional land use degree; $A_{i}$ is the grading index of land use level $i$; $C_{i}$ is the area percentage of land use level $i$; and $n$ is the classification number of land use degree.

\section{Results and analysis}

\subsection{Land use quantity change characteristics}

The distribution of land-use types in the Manas River Basin during the study period is shown in Figure 2, and the descriptive statistics for the land use are given in Table 1. In the past 50 years, the areas of dry land, residential land and meadow in the study area exhibited an obvious increasing trend, while grassland, sparse grassland, sparse shrub forest and glacier/permanent snow exhibited a decreasing trend. The areas of other types of land use changed relatively little. Eight types of land use exceeded $1000 \mathrm{~km}^{2}$ : dry land, sparse shrub forest, grassland, meadow, sparse grassland, bare soil, bare rock and glacier/ perpetual snow. 

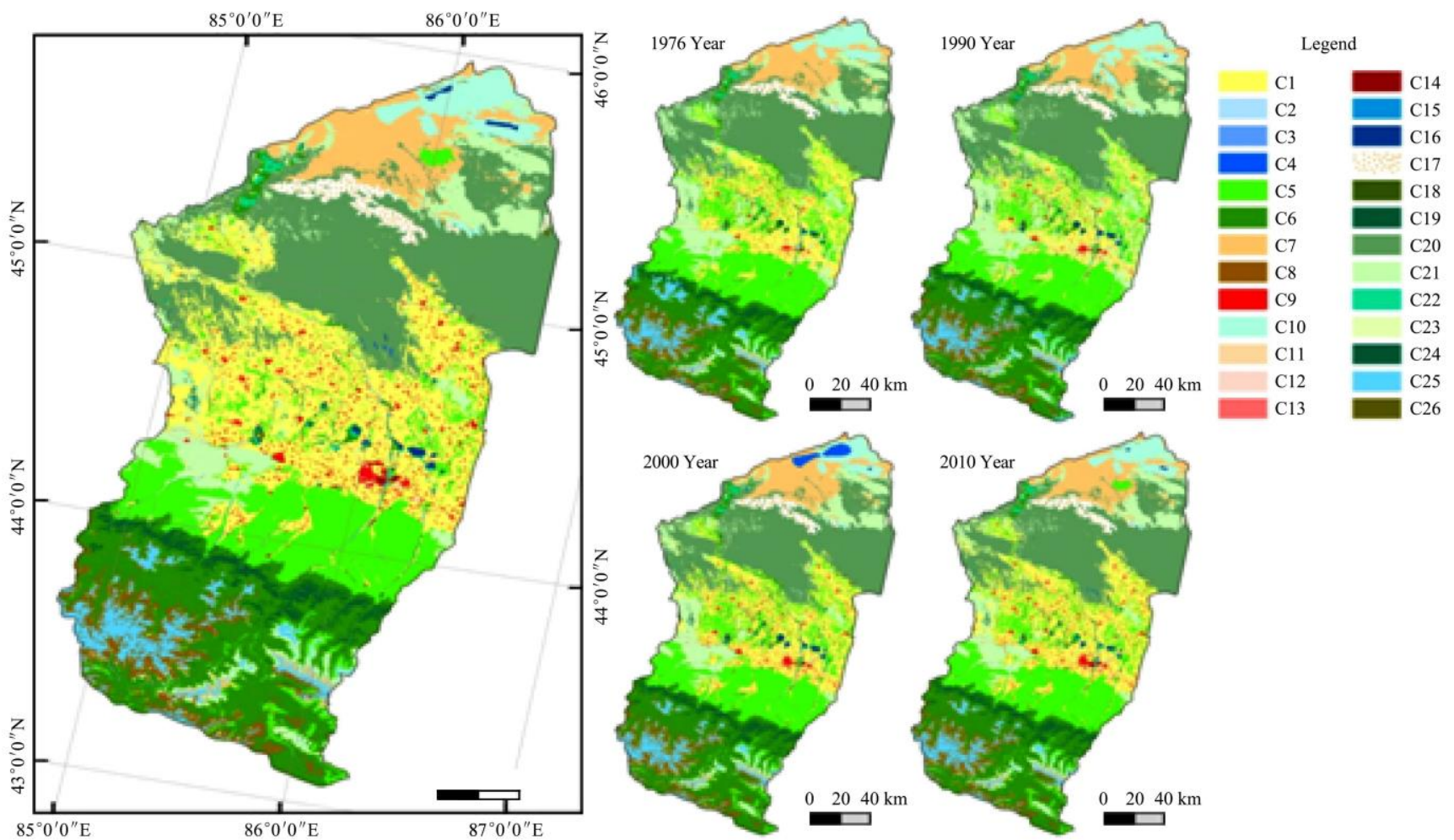

Note: C1. Dry land; C2. Paddy field; C3. Rivers; C4. Lake; C5. Grassland; C6. Meadow; C7. Bare soil; C8. Bare rock; C9. Residential land; C10. Saline-alkali land; C11. Arbor plot; C12. Arbor greenbelt; C13. Road land; C14. Industrial land; C15. Canal; C16. Pond; C17. Desert and sandy land; C18. Shrub land; C19. Evergreen needleleaf forest; C20. Sparse shrub forest; C21. Sparse grassland; C22. Herbaceous swamp; C23. Herbaceous greenbelt; C24. Deciduous broad-leaved forest; C25. Glacier/permanent snow; C26. Deciduous broad-leaved shrub forest).

Figure 2 Land use classification of the Manas River Basin (1976-2015)

Table 1 Changes in land-use types in the Manas River Basin,

1976-2015

\begin{tabular}{|c|c|c|c|c|c|}
\hline \multirow{2}{*}{ Land-use type } & \multicolumn{2}{|c|}{$\begin{array}{l}\text { Before water-saving } \\
\text { practices } / \mathrm{km}^{2}\end{array}$} & \multicolumn{3}{|c|}{$\begin{array}{l}\text { After water-saving practices } \\
\qquad / \mathrm{km}^{2}\end{array}$} \\
\hline & 1976 & 1990 & 2000 & 2005 & 2015 \\
\hline Glacie & 1556.00 & 1459.62 & 1215.67 & 1215.22 & 1215.19 \\
\hline Herbal green land & 9.14 & 9.37 & 9.88 & 9.56 & 10.01 \\
\hline Herbal marsh & 113.92 & 126.32 & 126.01 & 118.71 & 116.45 \\
\hline Meadow & 4537.29 & 4605.10 & 4728.40 & 4646.32 & 4658.05 \\
\hline Grassland & 5454.55 & 5654.51 & 5522.70 & 5205.50 & 4577.33 \\
\hline $\begin{array}{l}\text { Evergreen } \\
\text { coniferous forest }\end{array}$ & 552.68 & 529.82 & 552.58 & 552.58 & 552.60 \\
\hline Industrial land & 15.39 & 15.84 & 15.41 & 27.13 & 30.00 \\
\hline Shrub green & 0.04 & 0.06 & 0.04 & 0.50 & 0.50 \\
\hline Dry land & 3218.79 & 4579.20 & 5348.60 & 6170.42 & 7424.90 \\
\hline River & 131.83 & 131.48 & 131.56 & 137.89 & 133.02 \\
\hline Lake & 5.39 & 0.35 & 222.78 & 6.07 & 7.96 \\
\hline Roadway & 36.70 & 20.52 & 52.89 & 58.31 & 59.69 \\
\hline Residential land & 197.29 & 262.18 & 383.47 & 431.86 & 454.80 \\
\hline Bare soil & 1921.09 & 2140.16 & 2140.14 & 2074.12 & 2052.15 \\
\hline Bare rock & 1171.24 & 1119.14 & 1171.87 & 1172.83 & 1164.08 \\
\hline $\begin{array}{l}\text { Deciduous broad- } \\
\text { leaved shrub forest }\end{array}$ & 45.45 & 45.80 & 45.27 & 29.42 & 21.54 \\
\hline $\begin{array}{l}\text { Deciduous broad- } \\
\text { leaved forest }\end{array}$ & 105.66 & 107.65 & 105.59 & 96.11 & 87.37 \\
\hline Tree greenbelt & 2.22 & 2.57 & 2.51 & 2.86 & 2.86 \\
\hline Tree garden & 10.67 & 10.70 & 10.65 & 19.52 & 17.98 \\
\hline Desert/Sandy land & 492.79 & 491.97 & 492.53 & 492.53 & 492.50 \\
\hline Pond & 102.96 & 47.02 & 109.49 & 79.22 & 109.58 \\
\hline Paddy field & 12.07 & 17.13 & 16.83 & 17.01 & 12.61 \\
\hline Sparse grassland & 5462.43 & 4082.45 & 3290.35 & 3076.83 & 2818.77 \\
\hline Sparse shrub forest & 7655.59 & 7695.43 & 7627.94 & 7487.12 & 7117.14 \\
\hline Saline alkali soil & 1171.78 & 958.79 & 723.55 & 919.11 & 909.73 \\
\hline Canal & 3.60 & 4.24 & 3.63 & 3.63 & 3.54 \\
\hline Total & 34050.35 & 34050.35 & 34050.35 & 34050.35 & 34050.35 \\
\hline
\end{tabular}

\subsubsection{Analysis of land use area changes}

The most important land-use types of the Manas River Basin were grouped into six categories: cultivated land, development land, grassland, forest land, water and unused land. The main changes in the areas of these land-use categories are described below.

\section{(1) Changes in cultivated land area}

The area of cultivated land in the Manas River Basin increased significantly from 1976 to 2015. Before the implementation of water-saving technology, the area of cultivated land increased from $3230.86 \mathrm{~km}^{2}$ in 1976 to $5365.43 \mathrm{~km}^{2}$ in 2000 (an increase of $66 \%$ at an average annual growth of $85.4 \mathrm{~km}^{2} / \mathrm{a}$ ). After the implementation of water-saving technology, the cultivated land area increased from $5365.43 \mathrm{~km}^{2}$ in 2000 to $7437.52 \mathrm{~km}^{2}$ in 2015 (an increase of 38\% at an average annual growth rate of $\left.138.1 \mathrm{~km}^{2} / \mathrm{a}\right)$. The rate of increase in the area of dry land before and after the implementation of water-saving technology was $85.2 \mathrm{~km}^{2} / \mathrm{a}$ and $138.4 \mathrm{~km}^{2} / \mathrm{a}$, respectively, whereas the paddy field area changed little $^{[24]}$.

The rapid expansion of cultivated land in the basin 
was mainly caused by changes in irrigation and urbanization in different periods. Before 1976, irrigation was inefficient because it relied mainly on river diversion and surface water development. From 1976 to 1999, surface water and groundwater sources were combined through the use of reservoirs, channels and wells. Since 1999, drip irrigation has been adopted in the basin, and the farmland has utilized efficient water-saving irrigation, leading to a rapid expansion in cultivated land area.

(2) Changes in development land area

Between 1976 and 2015, the area of development land expanded by $118 \%$ in the basin, from $249.38 \mathrm{~km}^{2}$ in 1976 to $544.49 \mathrm{~km}^{2}$ in 2015 . Among the various types of development, residential land accounted for the largest proportion, increasing by $234.6 \mathrm{~km}^{2}(123.5 \%)$ in the 50-year study period. The annual rate of growth in development land area before and after the implementation of water-saving technology was $8.1 \mathrm{~km}^{2} / \mathrm{a}$ and $6.2 \mathrm{~km}^{2} / \mathrm{a}$, respectively. The average annual growth in the area of residential land area before and after adoption of water-saving technology was $7.4 \mathrm{~km}^{2} / \mathrm{a}$ and $4.8 \mathrm{~km}^{2} / \mathrm{a}$, respectively. During the study period, the proportions of development land devoted to transportation and industry showed increasing trends, although the trend was small. These changes were inextricably linked with the rapid expansion of industrial development and infrastructure construction in recent years.

(3) Changes in grassland area

The area of grassland in the basin was significantly reduced (by 22\%) from $15463.4 \mathrm{~km}^{2}$ in 1976 to $12064.16 \mathrm{~km}^{2}$ in 2015. Before the implementation of water-saving technology, the grassland area in the basin decreased from $15463.4 \mathrm{~km}^{2}$ in 1976 to $13551.3 \mathrm{~km}^{2}$ in $2000(12 \%)$. After the implementation of water-saving technology, the grassland area in the basin decreased from $13551.3 \mathrm{~km}^{2}$ in 2000 to $12064.16 \mathrm{~km}^{2}$ in 2015 (11\%). The grassland area of the basin was concentrated mainly in the upper reaches of the mountainous area. The application of water-saving technology mainly affected the oasis and desert areas in the middle and lower reaches of the basin. Due to changes in human activity (i.e., reclamation of areas for farmland and other land use) and in the natural environment (e.g., grassland degradation), the grassland and sparse grassland areas in the upper reaches of the basin decreased substantially.

(4) Forest area change

From 1976 to 2015, the forest area in the basin changed little, decreasing only slightly (7\%) from $8372.30 \mathrm{~km}^{2}$ in 1976 to $7799.99 \mathrm{~km}^{2}$ in 2015 . Before and after the implementation of water-saving techniques, the areas of evergreen coniferous forest and shrub forest in the upper reaches of the mountain changed little, and the green space and garden area occupied by trees in the middle and lower oasis areas showed a slight increase. The change of forest land area was caused mainly by changes in the area of sparse shrub forest located in the downstream desert area. Before the implementation of water-saving technology, the shrubbery area was relatively stable at $7600 \mathrm{~km}^{2}$, and after implementation of the water-saving technology the shrub forest area decreased from $7627.94 \mathrm{~km}^{2}$ in 2000 to $7117.14 \mathrm{~km}^{2}$ in 2015, an average annual decrease of $34.1 \mathrm{~km}^{2} / \mathrm{a}$. This change was due to increases in industrial and agricultural water use in the middle and upper reaches of the basin so that the downstream water level gradually decreased, affecting the ecological environment of the desert area vegetation, including the genera, Haloxylon and Tamarix, and other shrubs.

(5) Change in water price

The area of water in the basin from 1976 to 2015 increased from $357.69 \mathrm{~km}^{2}$ in 1999 to $593.47 \mathrm{~km}^{2}$ in 2000 and then decreased to $370.54 \mathrm{~km}^{2}$ in 2015 . In the Manas River Basin, wetlands and reservoirs connected to the river in irrigation areas comprise the farmland water supply system to ensure an adequate water supply. Thus, between 1976 and 2000, the change in the area of water was reflected mainly in increased areas of lakes and the reservoirs. However, the surface area of artificial irrigation channels also contributed to the increased area of water. In the 1990s, a large number of irrigation channels were constructed having a "V-shaped" cross-section; for such a configuration the surface area of water in the channels is directly related to the amount of 
surface water used for irrigation. Consequently, water area attributed to channels increased significantly from 1976 to 2000. After 2000, due to the promotion of water-saving technology on irrigated farms, irrigation and drainage gradually decreased, as did water area in channels.

(6) Unused land area change

Between 1976 and 2015, the unused land area of the basin gradually decreased, from $6312.90 \mathrm{~km}^{2}$ in 1976 to $5833.65 \mathrm{~km}^{2}$ in $2015(8 \%)$. The unused land was dominated by glacier/perpetual snow and bare rock. Both before and after implementation of water-saving technology, the glacier/permanent snow area decreased, but bare rock, saline alkali land and desert area changed little. The area of bare soil before the large-scale popularization of water-saving technology, increased from $1921.1 \mathrm{~km}^{2}$ in 1976 to $2140.1 \mathrm{~km}^{2}$ in 2000 , mainly due to the unreasonable development of water and soil resources for human activities. After a large area of the basin implemented water-saving technology to address the process of oasis formation, the area of bare soil was reduced from $2140.1 \mathrm{~km}^{2}$ in 2000 to $2052.2 \mathrm{~km}^{2}$ in 2015 , a reduction of nearly $100 \mathrm{~km}^{2}$.

\subsubsection{Analysis of land use dynamics}

Table 2 shows that the proportion of cultivated land area and development land area increased in the years 1976 to 2015, while the proportion of areas existing as unused land, forest land, grassland and water declined. Analysis of the comprehensive degree of land use shows that the degree of land use in the Manas River Basin also increased, indicating that the degree of human disturbance intensified.

The oasis area increased from $3480.2 \mathrm{~km}^{2}$ in 1976 to $4894.9 \mathrm{~km}^{2}$ in 1990 , then to $5817.2 \mathrm{~km}^{2}$ in 2000 and to $6704.7 \mathrm{~km}^{2}$ in 2010 , and finally to $7982.0 \mathrm{~km}^{2}$ in 2015 . In the period, 1976 to 2015, the increase in oasis area (40.6\%) was the most obvious in 1976-1990, and the slowest (15.3\%) in 2000-2010. The oasis expansion in 1990-2000 and 2010-2015 was $18.8 \%$ and $19.1 \%$, respectively. Over the 50-year study period, oasis area increased by $129.4 \%$. The expansion of oasis area in different periods of the Manas River Basin was mainly caused by different levels of irrigation and urbanization.
Among the land use types, arable land and development land were relatively active. The dynamic degree of development land was the largest in 1990-2000, after which it first increased and then decreased. Cultivated land had the greatest dynamic degree in 2000-2015, and showed an increasing trend. Before the popularization of water-saving technology (1976-1990), the comprehensive dynamic degree of land use was $-0.03 \%$, during which the cultivated land was the most active, and forest land and unused land were relatively stable. In 1990-2000, the maximum dynamic value of development land was $5.1 \%$; also during this period the overall fluctuation of water area was large and the change was dramatic. After the promotion of water-saving technology (2000-2015), the dynamic degree of land type was the most active in 2000-2010, and the forest land was the most stable. Between 2010 and 2015, the cultivated land was the most active, the dynamic degree of forest land reached the extreme value of $-0.9 \%$, and unused land was the most stable.

Table 2 Changes in the extent (\%) of land-use types in the Manas River Basin, 1976-2015

\begin{tabular}{lcccc}
\hline \multirow{2}{*}{ Land-use type } & \multicolumn{4}{c}{ Periods of change } \\
\cline { 2 - 5 } & $1976-1990$ & $1990-2000$ & $2000-2010$ & $2010-2015$ \\
\hline Arable land & $3.0 \%$ & $1.7 \%$ & $3.1 \%$ & $4.0 \%$ \\
Development land & $1.4 \%$ & $5.1 \%$ & $2.9 \%$ & $1.1 \%$ \\
Grassland & $-0.5 \%$ & $-0.6 \%$ & $-0.9 \%$ & $-1.4 \%$ \\
Woodland & $0.0 \%$ & $-0.1 \%$ & $-0.4 \%$ & $-0.9 \%$ \\
Water & $-1.0 \%$ & $9.2 \%$ & $-8.4 \%$ & $1.4 \%$ \\
Unused land & $-0.2 \%$ & $-0.7 \%$ & $0.5 \%$ & $-0.1 \%$ \\
Comprehensive & $-0.03 \%$ & $0.02 \%$ & $0.00 \%$ & $0.00 \%$ \\
dynamic degree & & & & \\
\hline
\end{tabular}

\subsection{Spatial distribution characteristics of land use}

3.2.1 Analysis of land use type transformation and spatial distribution

The analysis of land-use type and spatial distribution is an important part of land use/cover research, and it is also the basis for analyzing the driving factors of land-use type conversion ${ }^{[25-28]}$. The areas of land-use types transformed in the Manas River Basin during the 50-year study period are shown in Table 3 and Figure 4. The spatial distribution is shown in Figure 2.

Before the promotion of water-saving technology (1976-2000, Table 3), $557.74 \mathrm{~km}^{2}$ of unused land was transformed to grassland area. Development land and 
grassland were transformed to farmland in the amounts of $137.53 \mathrm{~km}^{2}$ and $2542.93 \mathrm{~km}^{2}$, respectively. In the same period, $189.64 \mathrm{~km}^{2}$ of forest land transformed to grassland area and $93.46 \mathrm{~km}^{2}$ to cultivated land. The water area transformed mostly to grassland $\left(72.08 \mathrm{~km}^{2}\right)$; less transformed to other land-use types. The cultivated land transformed to grassland to the largest extent $\left(381.8 \mathrm{~km}^{2}\right)$, followed by transfer to development land $\left(232.82 \mathrm{~km}^{2}\right)$ and smaller transfers to other land-use types.

Table 3 Land use transfer matrix for the Manas River Basin before implementation of water-saving measures

\begin{tabular}{|c|c|c|c|c|c|c|c|}
\hline & Unused land & Development land & Grassland & Forest land & Water area & Cultivated land & Total area \\
\hline Unused land & 480.06 & 1.09 & 557.74 & 53.30 & 235.96 & 2.06 & 1330.22 \\
\hline Development land & 0.26 & 1.07 & 31.62 & 1.81 & 0.49 & 137.53 & 172.78 \\
\hline Grassland & 215.75 & 70.02 & 367.91 & 190.47 & 82.07 & 2542.93 & 3469.16 \\
\hline Forest land & 53.35 & 4.77 & 189.64 & 59.39 & 6.82 & 93.46 & 407.44 \\
\hline Water area & 8.71 & 0.52 & 72.08 & 6.98 & 22.00 & 10.40 & 120.68 \\
\hline Cultivated land & 1.14 & 232.82 & 381.80 & 27.75 & 8.48 & 3.74 & 655.73 \\
\hline Total area & 759.26 & 310.30 & 1600.79 & 339.72 & 355.82 & 2790.11 & 6156.02 \\
\hline
\end{tabular}

Table 4 Land use transfer matrix for the Manas River Basin after implementation of water saving technology

\begin{tabular}{|c|c|c|c|c|c|c|c|}
\hline & Unused land & Development land & Grassland & Forest land & Water area & Cultivated land & Total area \\
\hline Unused land & 7.45 & 0.28 & 108.67 & 10.40 & 34.85 & 6.55 & 168.19 \\
\hline Development land & 0.01 & 1.47 & 1.72 & 0.10 & 0.15 & 37.36 & 40.81 \\
\hline Grassland & 11.58 & 46.83 & 95.50 & 12.11 & 51.15 & 1756.24 & 1973.41 \\
\hline Forest land & 12.34 & 4.24 & 0.61 & 8.12 & 5.23 & 567.41 & 597.95 \\
\hline Water area & 226.44 & 1.34 & 64.46 & 3.12 & 39.33 & 27.93 & 362.63 \\
\hline Cultivated land & 0.27 & 79.36 & 215.28 & 19.51 & 8.99 & 6.76 & 330.16 \\
\hline Total area & 258.09 & 133.52 & 486.24 & 53.35 & 139.70 & 2402.24 & 3473.15 \\
\hline
\end{tabular}

After the promotion of water-saving technology (2000-2015, Table 4), unused land mainly transformed to grassland $\left(108.67 \mathrm{~km}^{2}\right)$. Development land, grassland and forest land each transformed to cultivated land in the amounts of $37.36 \mathrm{~km}^{2}, 1756.24 \mathrm{~km}^{2}$ and $567.41 \mathrm{~km}^{2}$, respectively. Water area transformed mostly to unused land $\left(226.22 \mathrm{~km}^{2}\right)$. Cultivated land transformed mainly to grassland $\left(215.28 \mathrm{~km}^{2}\right)$, followed by transfer to development land $\left(79.36 \mathrm{~km}^{2}\right)$ and smaller transfers to other land-use types.

A comparison of data in Tables 3 and 4 shows that the land transfer between development land and grassland land was consistent before and after water-saving technology implementation, and that both land-use types mainly transformed to cultivated land. Before and after the promotion of water-saving technology, unused land was transformed mostly to grassland, whereas the predominant transfer of forest land changed from grassland to cultivated land, respectively. Before the promotion of water-saving technology, water area transformed mostly to grassland, but afterward to unused land. Before and after the promotion of water-saving technology, the transfer of other types of land use to cultivated land was $111 \mathrm{~km}^{2} / \mathrm{a}$ and $160 \mathrm{~km}^{2} / \mathrm{a}$, respectively.

\subsection{Analysis of factors influencing land use change}

Because the process of land use change is influenced by many factors such as natural factors, social economy and others, the relationship between structure and function were examined from the perspective of driving force and landscape pattern change ${ }^{[29-32]}$.

\subsubsection{Index analysis of landscape pattern}

FRAGSTATS 3.4 software was used to analyze the landscape pattern index of the Manas River Basin; to calculate the patch shape, area change, fragmentation, diversity, and aggregation degree of the landscape types; and to analyze the temporal and spatial characteristics of landscape pattern over the 50-year study period. Four 
landscape indices were used: the Shannon diversity index (SHDI), spread index (CONTAG), average adjacent index (ENN_MN), and aggregation index (AI). Factor analysis was used to quantitatively analyze the driving factors of landscape pattern change.

Data in Figure 3 show that the values of all four landscape indexes increased from 1976 to 1990. The similarity of adjacent patches was low and the spatial distribution became more discrete, which indicated that landscape fragmentation and heterogeneity increased in in the basin during this time period. From 1990 to 2000, SHDI increased, whereas ENN_MN, AI and CONTAG decreased, which indicated that the landscape fragmentation and heterogeneity were further enhanced. From 2000 to 2010, ENN_MN, CONTAG and AI increased slightly. SHDI remained unchanged and the remaining indexes decreased, which indicated that landscape fragmentation and heterogeneity changed little. From 2010 to 2015, all landscape pattern indexes increased, indicating that landscape fragmentation and landscape heterogeneity were further enhanced.

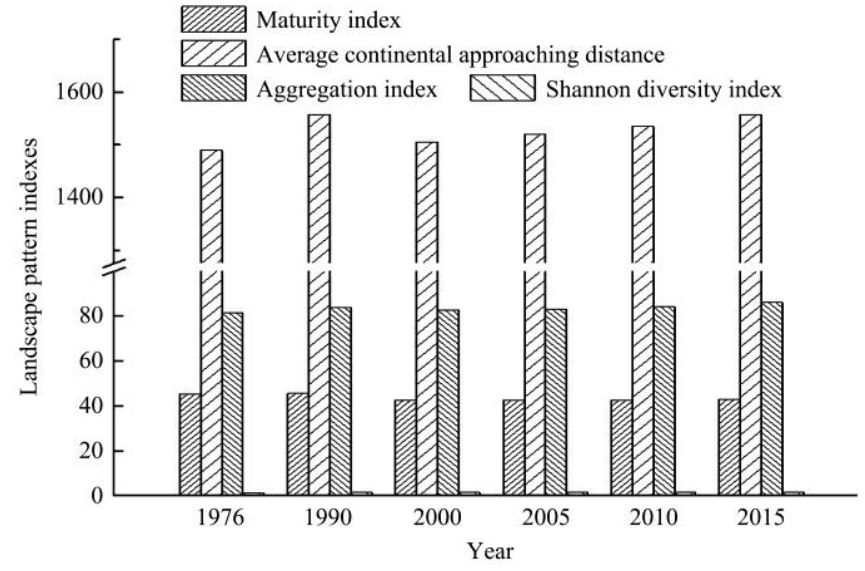

Figure 3 Changes in landscape pattern indexes, 1976-2015

\subsubsection{Driving force analysis}

The irrigation level and urbanization level during different time periods affected the expansion of oasis area in the Manas River Basin. Eight indicators were selected to analyze the effect: runoff $\left(X_{1}\right)$, gross domestic product $\left(X_{2}\right)$, precipitation $\left(X_{3}\right)$, the level of urbanization $\left(X_{4}\right)$, population $\left(X_{5}\right)$, the proportion of agricultural water $\left(X_{6}\right)$, the proportion of the second industry $\left(X_{7}\right)$, and groundwater depth $\left(X_{8}\right)$. Factor analysis was conducted using SPSS software to obtain three principal component factors, which are reported in Table 5.
Table 5 Principal component matrix of factors affecting expansion of oasis area in the Manas River Basin, 1976-2015

\begin{tabular}{cccc}
\hline & \multicolumn{3}{c}{ Principal component } \\
\cline { 2 - 4 } Variable & $\begin{array}{c}\text { First principal } \\
\text { component }\end{array}$ & $\begin{array}{c}\text { Second principal } \\
\text { component }\end{array}$ & $\begin{array}{c}\text { Third principal } \\
\text { component }\end{array}$ \\
\hline$X_{1}$ & -0.011 & 0.002 & 0.917 \\
$X_{2}$ & -0.593 & 0.721 & -0.146 \\
$X_{3}$ & 0.463 & 0.003 & 0.662 \\
$X_{4}$ & 0.929 & 0.137 & 0.129 \\
$X_{5}$ & 0.834 & 0.233 & 0.078 \\
$X_{6}$ & -0.937 & 0.079 & -0.070 \\
$X_{7}$ & 0.327 & 0.904 & 0.076 \\
$X_{8}$ & -0.692 & 0.107 & -0.274 \\
\hline
\end{tabular}

\section{Discussion}

(1) Effect of water saving measures on the ecological environment

Human activity in the Manas River Basin intensified during the 50-year study period (1976-2015) and the rapid social and economic development and population growth in the basin resulted in creation of a large amount of arable land; In about year 2000, drip irrigation under mulch technology was promoted in the basin, and the consequent one-sided pursuit of economic benefits resulted in a large area of basin reclamation, promoting the oasis process and city urbanization. After the water-saving technology was popularized, the groundwater level in the desert area of the lower reaches of the river basin was declined due to the irrigation recharge reduction.

(2) Effect of water saving measures of land use transformation

Before and after water-saving technology popularization, development land and grassland were mainly transformed to cultivated land area. Before and after the use of water saving technology, unused land area mainly changed to grassland area, but the predominant transfer of water area changed from grassland to unused land. Likewise, before and after the implementation of water-saving technology, the predominant transfer of forest land changed from grassland to farmland. The comprehensive dynamic degree of land use was most active before the popularization of water-saving technology, the fluctuation of water area was large, and the dynamic degree of unused land and forest land was stable. On the whole, the dynamic degrees of cultivated 
land and development land were relatively active.

\section{Conclusions}

In this study, remote sensing images of the Manas River Basin acquired in five time periods were selected to analyze the land use change processes (such as transfers of cultivated land, development land, grassland and forest land) resulting from the implementation of water-saving technology in the basin. The main conclusions are as follows:

(1) The construction of artificial oasis area increased from $3480.2 \mathrm{~km}^{2}$ to $7982.0 \mathrm{~km}^{2}$, the area of artificial oasis expanded 1.3 times. Before and after the implementation of water-saving measures, the average annual growth rate of cultivated land area was $85.4 \mathrm{~km}^{2} / \mathrm{a}$ and $138.1 \mathrm{~km}^{2} / \mathrm{a}$, respectively, while development land area increased by an average of $8.1 \mathrm{~km}^{2} / \mathrm{a}$ and $6.2 \mathrm{~km}^{2} / \mathrm{a}$, respectively. After the water-saving technology was popularized, the groundwater level in the desert area of the lower reaches of the river basin declined (due to reduced irrigation recharge), and the area of sparse shrub forest decreased by an average of $34.1 \mathrm{~km}^{2} / \mathrm{a}$. The grassland area of the basin decreased by $12 \%$ and $11 \%$, respectively, before and after water-saving technology popularization.

(2) After the promotion of water-saving technology, the amount of development land, grassland and forest land that transformed to cultivated land was $37.36 \mathrm{~km}^{2}$, $1756.24 \mathrm{~km}^{2}$ and $567.41 \mathrm{~km}^{2}$, respectively.

(3) After water-saving technology popularization, the dynamic degrees of cultivated land and water area were the most active, and that of forest land was the most stable. On the whole, the dynamic degrees of cultivated land and development land were relatively active. The promotion of water-saving techniques caused landscape fragmentation and landscape heterogeneity to increase. The city development level, economic development level and the dry humidity conditions were the main factors affecting river basin land use/cover change.

\section{Acknowledgements}

We acknowledge National Key Development Program (2017YFC0404303, 2017YFC0404304), the
Natural Science Funds (No. 41601579), Excellent Youth Teachers Program of Xinjiang Production\& Construction Corps (CZ027204).

\section{[References]}

[1] Bouwer H. Integrated water management: emerging issues and challenges. Agricultural Water Management, 2000; 45(3): 217-228.

[2] Pereira L S, Oweis T, Zairi A. Irrigation management under water scarcity. Agricultural Water Management, 2002; 57(3): 175-206.

[3] Brownpe. Land and land use. Science, 1936; 83(2154): 337-343.

[4] Foley J A, Defries R, Asner G P. Global consequences of land use. Science, 2005; 309(5734): 570-574.

[5] Lambin E F, Turner B L, Geist H J. The causes of land-use and land-cover change: moving beyond the myths. Global Environmental Change, 2001; 11(4): 261-269.

[6] Velzquez A, Dur N E, Ramirez I. Land use-cover change processes in highly biodiverse areas: the case of Oaxaca, Mexico. Global Environmental Change, 2003; 13(3): $175-184$

[7] Mooney H A, Duraiappah A, Larigauderie A. Evolution of natural and social science interactions in global change research programs. Proceedings of the National Academy of Sciences of the United States of America, 2013; 110(S1): 3665.

[8] Pielke R A. Land use and climate change. Science, 2005; 310(5754): 1625-1626.

[9] Verburg P H, Cje S, Witte N. Downscaling of land use change scenarios to assess the dynamics of European landscapes. Agriculture Ecosystems \& Environment, 2006; 114(1): 39-56.

[10] Tong S T Y, Sun Y, Ranatunga T. Predicting plausible impacts of sets of climate and land use change scenarios on water resources. Applied Geography, 2012; 32(2): 477-489.

[11] Tao C, Chen X, Lu J, Gassman P W, Sabine S, José-Miguel, S P. Assessing impacts of different land use scenarios on water budget of Fuhe River, China using SWAT model. Int J Agric \& Biol Eng, 2015; 8(3): 95-109.

[12] Rosa M D, Knudsen M T, Hermansen J E. A comparison of Land Use Change models: challenges and future developments. Journal of Cleaner Production, 2016; 113: 183-193.

[13] Wang S Y, Liu J Y, Zhang Z X. Analysis on spatial-temporal features of land use in China. Acta Geographica Sinica, 2001, 56(6): 639-647. (in Chinese)

[14] Tang J H, Wen W B, Yang P. Recent progresses of land use 
and land cover change (LUCC) models. Acta Geographica Sinica, 2009; 64(4): 456-468. (in Chinese)

[15] Liao J W, Zhou Y Z, Jiang Y. Study on the interaction of land-ocean in coastal zone based on LUCC. Economic Geography, 2012; 32(9): 138-142. (in Chinese)

[16] Zhao R F, Jiang P H, Chen Y N. Land use/cover change and its eco-environment effect in the main stream of Tarim River. Scientia Geographica Sinica, 2012; 32(2): 244-250. (in Chinese)

[17] Zhang C Y, Zhao Z J. Temporal and spatial change of land use/cover and quantitative analysis on the driving forces in the yellow river delta. Acta Scientiarum Naturalium Universitatis Pekinensis, 2015; 51(1): 151-158. (in Chinese)

[18] Liu Y Q, Long H L, Architectural F O. Land use transitions and their dynamic mechanism in the Huang-Huai-Hai Plain. Acta Geographica Sinica, 2016; 71(4): 66-79. (in Chinese)

[19] Yang G, He X L, Zheng T G. Integrated agricultural irrigation management technique in the arid inland area, China. Journal of Food Agriculture \& Environment, 2012; 10(10): 736-741.

[20] Yang G, He X L, Li J F. Water resource optimal allocation based on mathematical model in Manas River Basin, China. Journal of Computational \& Theoretical Nanoscience, 2015, 12(12): 6278-6281.

[21] Yang G, He X L, Zheng T G. Natural and artificially water flux ratio research in Arid Inland River Basin, China. Fresenius Environmental Bulletin, 2012; 21(7): 1764-1768.

[22] ENVI V5.1. https://en.wikipedia.org/wiki/Exelis_Visual_ Information_Solutions. Access on [2017-08-09]

[23] ARCGIS V10.1. http://www.arcgis.com/features/index.html. Access on [2017-08-09]

[24] Yang G, Chen J C, He X L. Ecological plant haloxylon ammodendron's response to drought stress and the model topredict the water environment. 2013.

[25] Burian S J, Brown M J, Mcpherson T N. Evaluation of land use/land cover datasets for urban watershed modeling.
Water science and technology: a journal of the International Association on Water Pollution Research, 2002; 45(9): 269-276.

[26] Fu B, Qi Y B, Chang Q R. Impacts of revegetation management modes on soil properties and vegetation ecological restoration in degraded sandy grassland in farming-pastoral ecotone. International Journal of Agricultural \& Biological Engineering, 2015; 8(1): 26-34.

[27] Liu H M, Cao L H, Xu C C. Distribution characteristics of soil organic carbon and nitrogen in farmland and adjacent natural grassland in Tibet. Int J Agric \& Biol Eng, 2016; 9(1): 135-145.

[28] Courault D, Bsaibes A, Kpemlie E. Assessing the Potentialities of FORMOSAT-2 Data for Water and Crop Monitoring at Small Regional Scale in South-Eastern France. Sensors (Basel, Switzerland), 2008; 8(5): 3460-3481.

[29] Ahmad M D, BiggsI T, Turral H. Application of SEBAL approach and MODIS time-series to map vegetation water use patterns in the data scarce Krishna river basin of India. Water science and technology: a journal of the International Association on Water Pollution Research, 2006; 53(10): 83-90.

[30] Akhtaruzzaman M, Osman K T, Haque S M S. Properties of soils under different land uses in Chittagong Region, Bangladesh. Journal of forest and environmental science, 2015; 31(1): 14-23.

[31] Liu P, Zheng X Q, Chen J F. Characteristic analysis of ecosystem service value of water system in Taiyuan urban district based on LUCC. Int J Agric \& Biol Eng, 2016; 9(1): $156-165$

[32] Yang G, He X L, Li X L, Long A H, Xue L Q. Transformation of surface water and groundwater and water balance in the agricultural irrigation area of the Manas River Basin, China. Int J Agric \& Biol Eng, 2017; 10(4): $107-118$ 